\title{
Social representations of transsexual women living with HIV/AIDS
}

\author{
Representações sociais de mulheres transexuais vivendo com HIV/Aids \\ Representaciones sociales de mujeres transexuales que viven con el VIH/Sida
}

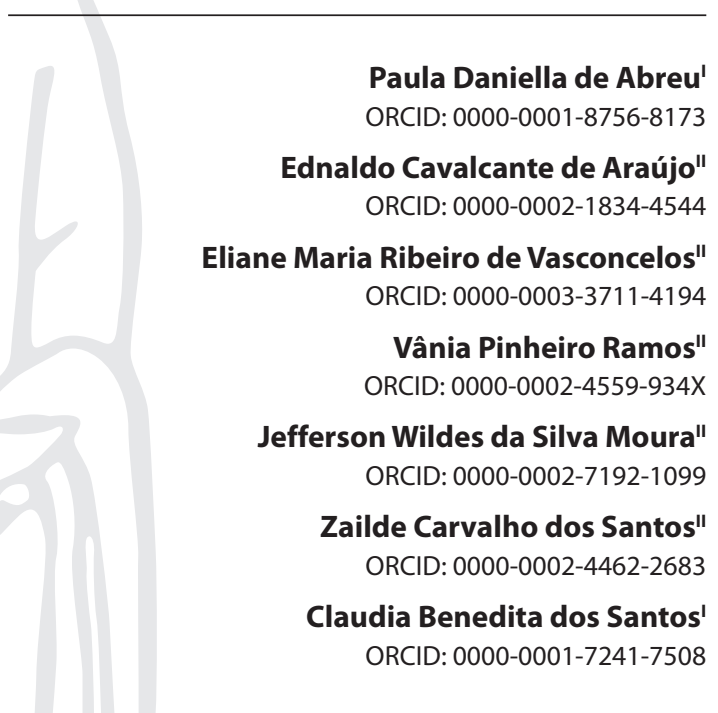

'Universidade de São Paulo. Ribeirão Preto, São Paulo, Brazil.

"Universidade Federal de Pernambuco. Recife, Pernambuco, Brazil.

How to cite this article: Abreu PD, Araújo EC, Vasconcelos EMR, Ramos VP, Moura JWS, Santos ZC, et al. Social representations of transsexual women living with HIV/Aids. Rev Bras Enferm. 2020;73(3):e20180390. doi: http://dx.doi.org/10.1590/0034-7167-2018-0390

Corresponding author:

Paula Daniella de Abreu E-mail: pauladdabreu@gmail.com

EDITOR IN CHIEF: Dulce Aparecida Barbosa ASSOCIATE EDITOR: Elucir Gir

Submission: 02-06-2019 Approval: 05-07-2019

\begin{abstract}
Objectives: identify the social representations of transsexual women living with HIV/AIDS. Methods: this is a qualitative descriptive exploratory study, based on the theory of social representations, conducted with six HIV/AIDS seropositive transsexual women from a hospital for patients with HIV/AIDS. For data collection, semi-structured interviews were conducted and later transcribed and analyzed with the help of Iramuteq (version 0.7) to produce a dendrogram of the descending hierarchical classification. Results: data were grouped into three classes: social thought and health/disease process; subjectivity and identity coping; and social determination and the context of vulnerability. Final Considerations: the elements of social representations were identified, based on commonsense knowledge, resulting from the way of thinking and acting and associated with the syndrome and social actors and sectors of the daily life of transsexual women. This study highlights the relevance of representational processes for humanized health care.

Descriptors: Nursing; Transgender Persons; Acquired Immunodeficiency Syndrome; HIV; Social Theory.
\end{abstract}

\section{RESUMO}

Objetivos: identificar as representações sociais de mulheres transexuais vivendo com HIV/Aids. Métodos: estudo qualitativo, descritivo e exploratório, ancorado à teoria das representações sociais, realizado com seis mulheres transexuais soropositivas, num hospital de referência para pessoas com HIV/Aids. Realizaram-se, para a produção dos dados, entrevistas semiestruturadas, posteriormente transcritas e analisadas com o auxílio do software Iramuteq (versão 0.7) para compor o dendograma a partir da classificação hierárquica descendente. Resultados: obteve-se o agrupamento dos dados em três classes: pensamento social e o processo saúde/ doença; subjetividade e o enfrentamento identitário; e determinação social e o contexto de vulnerabilidade. Considerações Finais: identificaram-se os elementos que compõem as representações sociais, objetivadas no conhecimento construído pelo senso comum, oriundos do modo de pensar e agir, associados à síndrome e aos atores e setores sociais no cotidiano das mulheres transexuais. Enaltece-se a relevância dos processos representacionais para o cuidado em saúde de forma humanizada.

Descritores: Enfermagem; Pessoas Transgênero; Síndrome da Imunodeficiência Adquirida; HIV; Teoria Social.

\section{RESUMEN}

Objetivos: identificar las representaciones sociales de las mujeres transexuales que viven con el VIH/Sida. Métodos: estudio cualitativo, descriptivo y exploratorio, basándose en la teoría de las representaciones sociales, en el cual participaron seis mujeres transexuales seropositivas, en un hospital de referencia a personas con el VIH/Sida. En la recolección de datos, se hizo entrevistas semiestructuradas, siendo posteriormente transcriptas y analizadas con el auxilio del software Iramuteq (versión 0.7) para componer el dendograma a partir de la clasificación jerárquica descendente. Resultados: se agruparon los datos en tres clases: pensamiento social y el proceso salud/enfermedad; subjetividad y el enfrentamiento identitario; y determinación social y contexto de vulnerabilidad. Consideraciones Finales: se identificaron los elementos que componen las representaciones sociales, que buscan construir un conocimiento mediante el sentido común, siendo provenientes del modo de pensar y de actuar, asociados al síndrome y a los actores y sectores sociales en el cotidiano de las mujeres transexuales. Se pone en relieve la relevancia de los procesos representacionales para el cuidado de la salud de forma humanizada.

Descriptores: Enfermería; Personas Transgénero; Síndrome de Inmunodeficiencia Adquirida; VIH; Teoría Social. 


\section{INTRODUCTION}

According to estimates, on average, 0.4 to $1.3 \%$ of people over 15 years old do not identify with assigned sex at birth, leading to 25 million transgender persons in the world, and between 752,000 and 2.4 million transsexual people in Brazil(1).

Self-identification is one way to understand what is fact is an identity, "I am a woman", then transsexual women can be defined as "those who, for themselves and society, have become women, although they were raised to be men because of the genitals with which they were born"(2).

Transsexuality may not be considered a disease, but it may be in the International Classification of Diseases (ICD) to ensure the transsexualization process by the Brazilian Health System (SUS). Despite the progress with transsexuality reclassification as a sexual health condition, and no longer as a mental illness, it still needs greater social and health visibility to recognize and depathologize gender identity that considers expressions, experiences, desires and feelings of the female universe that define them ${ }^{(3-4)}$.

In 1980, more consistent cases of transsexual women were reported with the association with prostitution in Paris ${ }^{(4)}$. Human immunodeficiency virus (HIV) and acquired immunodeficiency syndrome (AIDS) can be considered a social phenomenon linked with stereotypes of "sex, blood and death"(5), which was linked with the female transsexual population based on the idea of "risk and promiscuity", with an allusion to the "risk groups" and evident stigma regarding the lesbians, gays, bisexuals, transvestites and transsexual (LGBT) people(4).

AIDS was first reported in the United States in 1980, and in 1982 in Brazil. At first, it was characterized as an unknown feared disease of fast lethality and soon the idea that "who you are" was more emphasized than "what you do"(6). Then in 1981 in the United States, the "gay syndrome", the thinness of cholera, the virulence of plague, the spread of cancer, and the transmissibility of syphilis became more popular ${ }^{(7)}$.

Then HIV/AIDS prevention in public health was developed in three stages: the first one was focused on so-called "risk groups" for the LGBT people; the second stage basically considered the "risk behaviors", referring to one's blame for factual actions; and the third phase instituted the concept of vulnerability to the understanding that all individuals are susceptible to $\mathrm{HIV}^{(7)}$.

Considering the concept of vulnerability, the health/disease process involves individual, collective and programmatic dimensions. The first dimension refers to knowledge, information and attitudes in response to problems that may interfere in the protective conduct, the second dimension refers to economic, religious and social aspects in the health-disease process, and the third dimension refers to the ability of the institutions, especially health services, to minimize problems, based on policies and articulated with social sectors/actors: education, justice, culture and social well-being when addressing HIV/AIDS by social groups ${ }^{(8)}$.

This study seeks to identify social representations to understand socially constructed and shared phenomena, which become familiar when satisfying the argumentative reasoning of common sense ${ }^{(9)}$. Social phenomena are understood as an essential resource for interpreting the daily life of people or social groups and constitute an important tool of nursing for the criticality of social and scientific knowledge. Then, the following study question was defined: What are the social representations of transsexual women living with HIV/AIDS?

\section{OBJECTIVES}

To identify the social representations of transsexual women living with HIV/AIDS.

\section{METHODS}

\section{Ethical aspects}

This study is part of a dissertation developed under the graduate program in nursing of Universidade Federal de Pernambuco (UFPE), observing the guidelines of Resolution 466, of December 12,2012 , of the National Health Council of the Ministry of Health, which provides regulations for research involving human beings. Data collection started after approval of the research project by the Research Ethics Committee of Centro de Ciências da Saúde - CCS/ UFPE. This project also observed the guidelines of Resolution 510, of April 7, 2016, of the National Health Council of the Ministry of Health, as it analyzed the social context of vulnerability of young transsexuals to contribute to health services when situations or attitudes that may be considered illegal are reported, which may put women at risk. The researcher-participant relationship was continuously built during the study process through free dialogue between subjectivities, which implies reflexivity and building of non-hierarchical relationships, based on trust between researcher and participant and verbalizations and expressions, since ethics is a human, and therefore, historical, social and cultural construction ${ }^{(10)}$.

\section{Study design}

This is a qualitative descriptive exploratory study, based on the theory of social representations of Serge Moscovici and followers, which has been assigned intelligible forms to understand social practices in the historical, cultural and iconic context. In this sense, what used to be considered a concept is now understood as a phenomenon ${ }^{(9)}$.

\section{Study site}

This study was conducted at an HIV/AIDS outpatient service of Hospital Correia Picanço, located in Recife, capital of the State of Pernambuco, Brazil.

\section{Participants}

The study was conducted with six young transsexual women. The response saturation criterion was adopted to create the study sample ${ }^{(11)}$, using the definition of 'youth' of the Ministry of Health and the World Health Organization (WHO) ${ }^{(12)}$, that is, the 15-24 year age group.

This study included young people over 18 years of age who reported themselves as female transsexuals, without transgenitalization surgery, heterosexual, seropositive or in treatment for 
AIDS, and with casual partners. People with the characteristics mentioned above with hearing impairment were excluded (because the researcher had no skills in Brazilian sign language - BSL). The multidisciplinary team facilitated contact with study participants.

The identity of all participants remained confidential information and the names were replaced by song titles or names of Brazilian singers related to the context of social vulnerability.

\section{Data collection and organization}

Data were collected from April to June 2017, using a form with questions of participant characterization and a semi-structured interview with three study questions: 1) Tell me about your story; 2) Tell me what HIV/AIDS prevention means to you; 3) How do you see HIV/AIDS prevention in the group of transsexual women? Interviews were recorded and later fully transcribed; on average they lasted 1 hour and 10 minutes.

The participants were invited to participate in this study while they were in the waiting room of the hospital and, once they accepted, they were taken to a room dedicated by the institution for individual interviews.

Through the interview, verbal communication provided information about the study content as it has representations: acting, thinking and feeling under the influence of social dynamics ${ }^{(11)}$. The construction of knowledge and perceptions was explored to learn more about the interviewees in social interactions building representations and conceptions of meaning ${ }^{(13)}$. Semi-structured interviews allowed interviewees to freely discuss the study questions ${ }^{(11)}$. The interviews had a flexible design, which only helped the researcher consider all relevant aspects for the study ${ }^{(14)}$.

Participants were contacted by progressive inclusion, using the response saturation criterion ${ }^{(11)}$. Saturation occurs when depth, comprehensiveness and diversity are reached, allowing an understanding of representations, conceptions, ideas and meanings attributed to the phenomenon analyzed according to a theory, by questioning its multiple facets and interconnections, with no concern about generalization ${ }^{(15)}$.

\section{Data analysis}

Data analysis was conducted with the help of Interface de $R$ pour lês Analyses Multidimensionnelles de Textes et de Questionaires (Iramuteq), version 0.7, alpha 2, and descending hierarchical classification (DHC). This analysis consisted in obtaining classes from text segments (TS) classified according to their respective vocabularies; then they were distributed according to the frequency of reduced forms, based on matrices, and matching text segments and words in repeated chi-square tests (X2), DHC was applied and a stable and definitive classification was obtained ${ }^{(16)}$.

Iramuteq organized data analysis as a dendrogram, which illustrated the most frequent words, with greater association in classes and relations between them ${ }^{(17)}$. The classes were named after reading the text segments presented in the dendrogram and correlated according to the frequency of terms contained in the vocabulary, in order to understand the meaning in the speeches with rigor and depth ${ }^{(18)}$.

\section{RESULTS}

The social representations of the study group of six transsexual women reflected the'universe' of meanings about HIV/AIDS, supporting the study questioning. The study corpus had six texts from the speeches of the interviewees; they were submitted to analysis to obtain the DHC. After corpus processing, 338 text segments were obtained, listing 1,695 words with 11,909 occurrences. DHC retained $100 \%$ of total TS, since total corpus was effectively used, generating 3 classes: Class 3 with 111 TS, corresponding to $32.84 \%$ of total 338 TS; Class 2 with 139 TS, $41.12 \%$ of total 338 TS; and Class 1 with 88 TS, $26.04 \%$ of total 338 TS.

The corpus was divided into two subcorpora, as illustrated in Figure 1. The left subcorpus corresponded to Class 3, and the right subcorpus generated two subdivisions corresponding to Classes 2 and 1. All subcorpora represent the result of associations of words related to the study object: HIV/AIDS representation, which were statistically significant $(p<0.05)$ after applying the chi-square test, when considering the value of association with the class $(\geq 3.84)$.

When observing the $\mathrm{DHC}$, the most frequent terms refer to the symbolic, multicausal and subjective aspects of HIV/AIDS. After analyzing the dendrogram and reading the text segments, the following classes were defined: social thought and health/disease process (Class 3); subjectivity and identity coping (Class 2); and social determination and the context of vulnerability (Class 1 ).

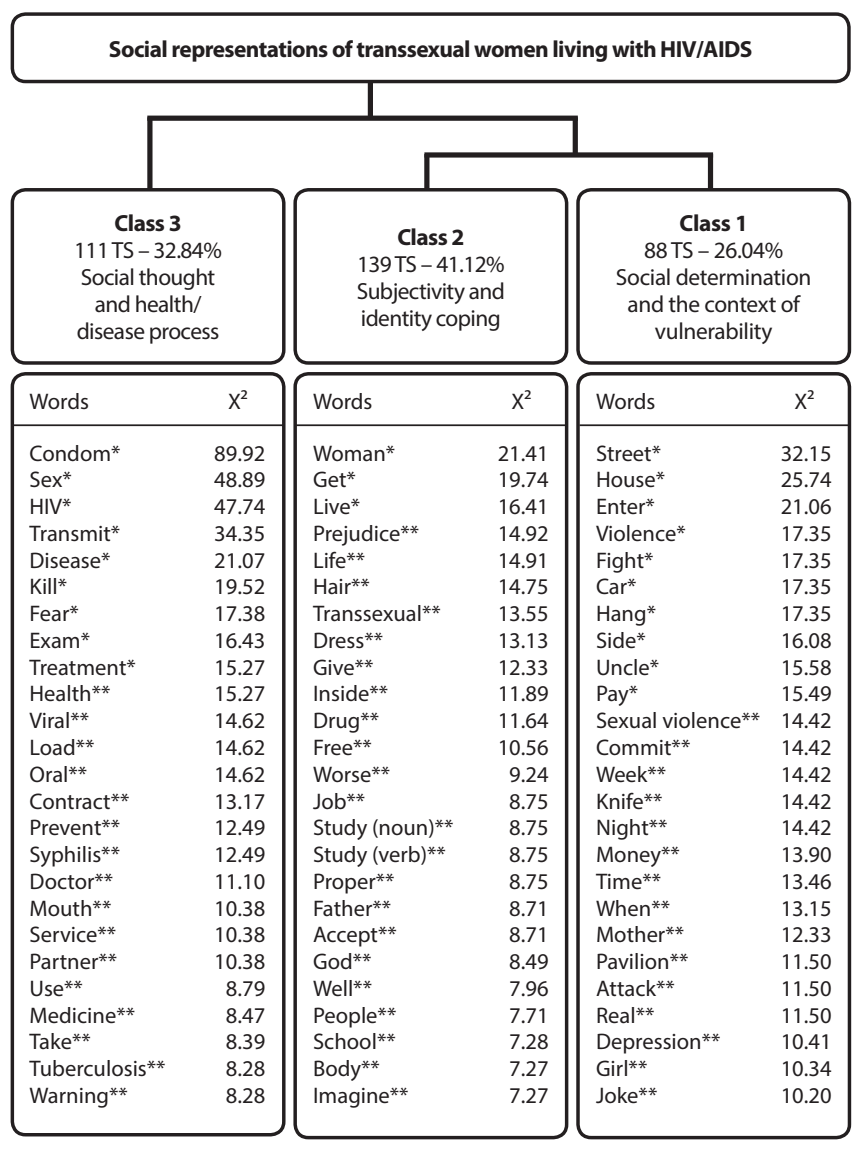

Note: ${ }^{*} p<0.0001 ;{ }^{* *} p<0.05 ;$ TS $=$ Text Segments.

Source: Corpus of analysis processed in Iramuteq (version 0.7, alpha 2).

Figure 1 - Dendrogram of descending hierarchical classification for the corpus about social representations of transsexual women regarding HIV/ AIDS prevention, Recife, Pernanmbuco, Brasil, 2017 


\section{DISCUSSION}

In Class 3, social thought and health/disease process, which corresponds to $32.84 \%$ of TS, the most frequent words were condom, sex, HIV, transmit, disease, kill, and fear. The health/disease process associated with materialization and figuration of transsexual women in the phenomenon of AIDS was also represented. The origin and transformation of the social representations of AIDS are seen in different relations with the youth, besides disease prevention, use of condom and the illness itself. The phenomenon of AIDS is highlighted with the influence of the prescriptive factors that will be reflected in the behaviors, since AIDS is considered 'a living questioning of everyday morals and ethics'(19).

The interviewees showed meanings of the disease related to the idea of death due to the impact of positive HIV/AIDS diagnosis. The opinion of transsexual women about themselves and the meaning attributed to the disease are reflected in the way they act through preventive behaviors and in the health/disease process, and, by considering positive HIV serology as 'the end of everything,' the mourning they experience can lead to lack of self-care:

The end of everything... I have to live today because tomorrow I don't know if I will be alive. When I got the result, it was positive, I tore the paper and said: I'll tell myself that I've never taken this exam... and I lived my life. (Ana Amsterdam)

I found out that I had HIV, it shocked me. Many are afraid to take the exam, when we talk we don't mention this subject because of this prejudice. (Elza Soares)

I only made things worse, I didn't use a condom, I took a very heavy load... I left there trembling, nervous, breathless. (Geni)

Hesitation in taking an exam to detect the virus and denial of the disease are configured as options to keep social relations, without discrimination, in family, social and work relations. Representation is associated with the idea of being close to physical and social death. Fear is not restricted to the lethal characteristic of the disease, as it also includes fear of experiencing the disease in an excluding and inhuman manner. A positive diagnosis of HIV/ AIDS can be compared to the metaphor of imminent death ${ }^{(20)}$.

In view of the chronicity of the disease and the psychological suffering, transsexual women present different ways to address their condition of seropositivity. Life after HIV shows strong grief that influences social relations and behaviors regarding the syndrome due to the idea of death that leads to feelings of hate and desire for revenge, according to the excerpts below:

Whoever has the disease, feels a desire for revenge, I already had that thought of doing it without a condom to kill. (Geni)

I didn't want to use a condom because I thought: it's just one more that I'm going to kill. In prostitution, how many fathers have I killed... I took the condom, made a hole in it with a needle, and I was glad that I had transmitted the same disease I had to someone else. (Ana Amsterdam)

Many have that pain in the heart, that hate inside: if someone transmitted it to me, I will transmit it to others. (Maria da Vila Matilde)
In Class 2, subjectivity and identity coping, which corresponds to $41.12 \%$ of TS, the most frequent words were: woman, get, live, prejudice, life, hair, and'transsexual. This class refers to issues of social ideology related to HIV/AIDS prevention involving social and ideological cleavages, resulting in a personification process of representations and producing an impact on the lives of transsexual women.

The association of transsexual women with prostitution and HIV/AIDS involves stigma and social exclusion. For the studied group, prostitution is a source of revenue due to social exclusion, especially early and violent exclusion from the family. Prostitution also produces a receptive environment to express femininity but exposes them to situations of vulnerability:

They were pressuring me too much [family]... I decided to leave and the world... what welcomes us as a transsexual? Just prostitution. (Ana Amsterdam)

I started in prostitution and I ended up getting HIV on the street when I was 14/15 years old. (Gisberta)

I've already been raped, I was about 15 years old, in front of my house, there was... the other time, when I started to make money I was on the street, then it happened, without a condom. (Geni)

Not all transsexual women are sex workers; this association leads to exclusion and reinforces social stigma and has to be demystified. Some of them work as prostitutes because they are excluded from other social environments; however, this context makes them susceptible to all types of violence ${ }^{(21-22)}$.

Social thought, when accepted by society, is incorporated by common sense and easily expressed in dialogues. The origin of historical and social elements that are perpetuated and comprise the language, environments and conceptions of everyday life is forgotten or hidden over time, but it is present in the construction of representations and ensures understanding, appropriation and meaning of the phenomena ${ }^{(12)}$.

The naturalization process of HIV/AIDS in the group of transsexual women is associated with lack of support, prejudice, and the idea of imminent death. Such behaviors result in poor dialogue, inadequate self-care, insufficient demystification of the disease, and poor visibility of gender identity:

The girls call each other HIV positive on the streets. For us it's a joke, it's common. (Benedita)

One calls the other HIV positive and says the other one is dead. They don't talk about seeking a health service, if one says something, the others will soon know about it. (Gisberta)

In our group, this subject is not frequently mentioned, I think there's a gap here, because many don't know a lot about it, many have the disease and don't know. (Elza Soares)

The development of ideas and images around the study object comes from social construction, culturally formulated in the memory of a specific group, that produces an impact on contemporaneity ${ }^{(23)}$.

When building the image of HIV/AIDS, the elements that constitute the reified discourse in social thought are revealed, conveying the idea of blame and accountability, particularly of 
individuals in the condition of seropositivity. Transsexual women consider seropositivity in the female transsexual context of both pejorative and silenced nature, which limits the relationships of mutual support, empowerment, exchange of knowledge, and visibility to address the disease.

In Class 1, social determination and the context of vulnerability, which represented $26.04 \%$ of TS, the most frequent terms were: street, house, enter, violence, fight, car, and hang. This class refers to circumstances of vulnerability to HIV/AIDS through social injustice, linked with an overlapping of prejudice constituted under the social ontological and prescriptive judgment of HIV/AIDS.

The interviewees revealed their life story with emphasis on social injustice. Discrimination, violence, insufficient resources, lack of family and social support, and seropositivity of transsexual women result in 'poor life conditions.'A dichotomous social thought is questionable as it segregates lives that are considered relevant to the detriment of those that are troublesome, marginalized and invisible.

Then, an 'abject' figure of transsexual women and the 'blessed' forms in society are identified through an analogy to Chico Buarque's song "Geni e o Zepelim."This context can be observed in the following excerpts:

They've already thrown terrible things at me: egg, coke, water, stone, everything, they always throw something on the street, tin, glass. (Geni)

Ileft home and started living on the street, sleeping under a bridge, abandoned houses... I started in prostitution, I started using drugs, I was arrested. (Ana Amsterdam)

I was raped too when I was 9 to 10 years old by my brother-in-law. (Maria da Vila Matilde)

According to this and other studies conducted in the Northeast region in Brazil, violence against transsexual people occurs in different social environments, first in the family, then in public places, health services, schools, especially on the streets, which are dangerous areas for transvestites and transsexuals ${ }^{(24-25)}$.

An overlapping of prejudice is observed due to gender identity and work in prostitution, where the context of marginalization plus social inequalities (lack of housing and employment combined with poverty and prejudice), lead to vulnerability to HIV/AIDS (25-27).

Social vulnerability regarding the representations of 'lives that matter' is observed in the speeches of interviewees:

I use condoms with customers, but not with people I want to have a relationship. They don't know that I have HIV... When a customer does oral sex on me, it is usually without a condom. (Gisberta)

In the jail they used to say: I'm going to have sex with you without a condom because I'm going to transmit HIV to you, you're going to get out of here dead. (Ana Amsterdam)

I charge more to do it without a condom, and they pay, they always pay to do it without a condom, all dead wanting to transmit the disease, and they pay. (Geni)

This class represents the image dimension based on the social image of HIV/AIDS associated with 'abject beings.' Vulnerability affects, in particular, those that do not perceive themselves as victims of poor conditions through the status of 'worthless' life, intrinsic to power relations in the social context ${ }^{(28)}$. Preventive behaviors are no longer for subjects with knowledge, experiences or resources for disease prevention, but aim the complexity of social relationships and the potential for addressing the challenges to health ${ }^{(8)}$.

Social representations about HIV/AIDS emerge as a social phenomenon to be identified in the life trajectory of young transsexual women, since it elucidated meanings and behaviors of this social group threatening their physical and psychic health. The impact of the epidemic along history reflects the social, cultural and political relations of the countries most affected by HIV/AIDS and social inequalities that involve cohesion of social classes (sexism and racism), unequal social capital, through vulnerability of individual, social and programmatic origin, which are factors that limit the access to decent and healthy life.

This study shows that nurses should to be prepared to act in case of inequalities related to gender identity and, above all, appreciate the personal trajectory and historical and social context of young transsexual women, recognizing them as subjects of rights, in order to expand discussions about discrimination related to HIV/AIDS and promote qualified listening, access to information, spaces for empowerment around rights and social inclusion. In addition, as reference professionals, they should act as operators of the social network dynamics, in the process of integration with family and community, and low-, mediumand high-complexity health services, enforcing the principles of universality, equity and integrality to guarantee human rights.

\section{Study limitation}

The phenomenon analyzed in this study is inserted in the historical, social, cultural and health care context, involving prejudices and stigmas, since social thought linked with moral concepts and personal beliefs instigate judgments that contribute to marginalization of transsexual women. This process may have hindered the collaboration and verbalizations of women during the study.

\section{Contributions to the area of nursing, health or public policy}

This study identified social representations in scientific implications that are relevant for nursing, politics and social construction, since the representational perspective does not establish definitive reasons, concepts or predeterminations, but it enables to confront tendencies, social changes and ideological trajectories in the relations between transsexual women and society when addressing the disease. Recognizing representational elements is essential for humanized care practices, especially for people in situations of vulnerability.

\section{FINAL CONSIDERATIONS}

The identification of social representations regarding HIV/AIDS provided an understanding of the organizational principles of mass communication, which have guided the representation of 
transsexual women over time. This process is present in social relations based on the context of individual, social and programmatic vulnerability in behaviors of HIV/AIDS prevention of these social subjects. Symbolic meanings were observed for AIDS in female transsexuality, violence, exclusion, fear and death, the elements that constitute the silence zone of the social representations analyzed in this study. Also, the importance of social representations was observed for professional coping and addressing actions in health, as it supports an analysis of representational processes in the social context and the meanings of objects built by the subjects in their daily life, which are the symbolic base for humanized practices in health care.

\section{FUNDING}

Source of funding: Projeto Procad (CAPES n: 23.038.000.984.2014-19).

\section{REFERENCES}

1. Winter S, Diamond M, Green J, Karasic D, Reed T, Whittle S, et al. Transgender people: health at the margins of society. Lancet [Internet]. 2016 [cited 2018 Mar 17];388(10042):390-400. Available from: https://www.ncbi.nlm.nih.gov/pubmed/27323925

2. Rodovalho AM. O cis pelo trans. Rev Estud Fem [Internet]. 2017 [cited 2018 Feb 15];25(1):365-73. Available from: http://www.scielo.br/pdf/ ref/v25n1/pt_1806-9584-ref-25-01-00365.pdf

3. Organização Pan-Americana da Saúde. Organização Mundial da Saúde. Perguntas e respostas: revisão da Classificação Internacional de Doenças (CID) [Internet]. 2018 Jan 8 [cited 2018 Mar 7]. Available from: http://www.paho.org/bra/index.php?option=com_content\&view=ar ticle\&id=5574:perguntase-respostas-revisao-da-classificacao-internacional-de-doencas-cid\&ltemid=875

4. Ministério da Saúde (BR). Secretaria de Gestão Estratégica e Participativa. Departamento de Apoio à Gestão Participativa. Transexualidade e travestilidade na saúde [Internet]. Brasília, DF: Ministério da Saúde; 2015 [cited 2018 Jan 9]. Available from: http://bvsms.saude.gov.br/bvs/ publicacoes/transexualidade_travestilidade_saude.pdf

5. Furtado FMSF, Santos JAG, Stedile L, Araújo E, Saldanha AAW, Silva J. 30 years later: social Representations about AIDS and sexual practices of rural towns residents. Rev Esc Enferm USP [Internet]. 2016 [cited 2017 Oct 22];50:074-080. Available from: http://www.scielo.br/pdf/ reeusp/v50nspe/pt_0080-6234-reeusp-50-esp-0074.pdf

6. Portinari DB, Wolfgang SMBM. Imagens e marcas: um imaginário ligado à epidemia de HIV-Aids no Brasil. ALCEU [Internet]. 2017 [cited 2017 Oct 22];17(34):45-60. Available from: http://revistaalceu.com.puc-rio.br/media/alceu34_pp45-60.pdf

7. Oliveira DC. Construction and transformation of social representations of Aids and implications for health care. Rev Latino-Am Enfermagem [Internet]. 2013 [cited 2017 Oct 22];21(Spec):1-10. Available from: http://www.scielo.br/pdf/rlae/v21nspe/pt_34.pdf

8. Ayres JRCM. Prevenção de agravos, promoção da saúde e redução da vulnerabilidade. In: Martins MA, Carrilho FJ, Alves VAF, Castilho EA, Cerri GG, Duarte AJS, et al. Clínica médica. Barueri: Manole; 2016. p. 436-54.

9. Moscovici S. Representações sociais: investigações em psicologia social. Petrópolis: Vozes; 2015.

10. Ministério da Saúde (BR). Resolução n 510, de 7 de abril de 2016. Diário Oficial da União [Internet]. 2016 May 24 [cited 2017 Oct 22];1:44. Available from: http://bvsms.saude.gov.br/bvs/saudelegis/cns/2016/res0510_07_04_2016.html

11. Minayo MCS. Pesquisa social: teoria, método e criatividade. Petrópolis: Vozes; 2015.

12. Ministério da Saúde (BR). Secretaria de Atenção à Saúde. Departamento de Ações Programáticas e Estratégicas. Proteger e cuidar da saúde de adolescentes na atenção básica [Internet]. Brasília, DF: Ministério da Saúde; 2017 [cited 2018 Feb 9]. Available from: http://189.28.128.100/dab/docs/portaldab/publicacoes/saude_adolecentes.pdf

13. Bauer MW, Gaskell G. Pesquisa qualitativa com texto, imagem, e som: um manual prático. Petrópolis: Vozes; 2015.

14. Yin RK. Pesquisa qualitativa: do início ao fim. Porto Alegre: Penso; 2016.

15. Minayo MCS. Sampling and saturation in qualitative Research: consensuses and controversies. Rev Pesq Qualitativa [Internet]. 2017 [cited 2018 Jan 17];5(7):1-12. Available from: https://editora.sepq.org.br/index.php/rpq/article/view/82/59

16. Reinert M. Alceste une méthodologie d'analyse des données textuelles et une application: Aurelia de Gerard de Nerval. SAGE [Internet]. 1990 [cited 2018 Feb 21];26(4):24-54. Available from: http://journals.sagepub.com/doi/pdf/10.1177/075910639002600103

17. Camargo BV, Justo AM. IRAMUTEQ: um software gratuito para análise de dados textuais. Temas Psicol [Internet]. 2013 [cited 2018 Apr 17];21(2):513-8. Available from: http://pepsic.bvsalud.org/pdf/tp/v21n2/v21n2a16.pdf

18. Creswell JW. Investigação qualitativa e projeto de pesquisa: escolhendo entre cinco abordagens. 3rd ed. Porto Alegre: Penso; 2014.

19. Abric C. Prácticas sociales y representaciones. México, DF: Coyoacán, 2001.

20. Machado YY, Oliveira DC, Nogueira VPF, Gomes AMT. Health personnel's social representations of HIV/AIDS: a structural analysis. Rev Enferm UERJ [Internet]. 2016 [cited 2017 Oct 22];24(1):e14463. Available from: http://www.facenf.uerj.br/v24n1/v24n1a12.pdf

21. Longaray DA, Ribeiro PRC. Transvestites and transsexuals: (trans)formed bodies and production of femininity. Estud Fem [Internet]. 2016 [cited 2017 Oct 22];24(3):761-84. Available from: http://www.scielo.br/pdf/ref/v24n3/1806-9584-ref-24-03-00761.pdf

22. Barret BJ, Sheridan DV. Partner violence in transgender communities: what helping professionals need to know. Journal of GLBT Family Studies 
[Internet]. 2016 [cited 2017 Oct 22];13(12):137-162. Available from: http://www.tandfonline.com/doi/abs/10.1080/1550428X.2016.1187104

23. Jesuíno JC, Mendes FRP, Lopes MJ, compilers. As representações sociais nas sociedades em mudança. Petrópolis: Vozes; 2015.

24. Silva RGLB, Bezerra WC, Queiroz SB. The impacts of transgender identities in sociability of travesties and transsexual women. Rev Ter Ocup Univ São Paulo [Internet]. 2015 [cited 2017 Oct 22];26(3):364-72. Available from: http://www.revistas.usp.br/rto/article/view/88052

25. Silva GWS, Souza EFL, Sena RCF, Moura IBL, Sobreira MVS, Miranda FAN. Cases of violence involving transvestites and transsexuals in a northeastern Brazilian city. Rev Gaúcha Enferm [Internet]. 2016 [cited 2017 Oct 22];37(2):e56407. Available from: http://www.scielo.br/pdf/ rgenf/v37n2/0102-6933-rgenf-1983-144720160256407.pdf

26. Smith LR, Yore J, Triplett DP, Urada L, Nemoto T, Raj A, et al. Impact of sexual violence across the lifespan on HIV risk behaviors among transgender women and cisgender people living with HIV. J Acquir Immune Defic Syndr [Internet]. 2017 [cited 2017 Oct 22];75(4):408-16. Available from: https://www.ncbi.nlm.nih.gov/pubmed/28653970

27. Ganju D, Saggurti N. Stigma, violence and HIV vulnerability among transgender persons in sex work in Maharashtra, India. Cult Health Sex [Internet]. 2017 [cited 2017 Oct 22];19(8):903-17. Available from: https://www.ncbi.nlm.nih.gov/pubmed/28132601

28. Seffner F, Parker R. The waste of experience and precariousness of life: contemporary political moment of the Brazilian response to AIDS. Interface [Internet]. 2016 [cited 2017 Oct 22];20(57):293-304. Available from: http://www.scielo.br/pdf/icse/v20n57/1807-5762icse-1807-576220150459.pdf 